\title{
THE USE OF GIS IN BROWNFIELD REDEVELOPMENT
}

\author{
Rebekah Boott, Mordechai Haklay, Kate Heppell, Jeremy Morley
}

\begin{abstract}
In recent years, the issue of Brownfield site development - the re-use of previously used urban land - has gained a significant place in the planning agenda. However, not all Brownfield sites are derelict or contaminated land, some are significant as environmental amenities - be it part of wider ecosystem or a green area for the local population. The growing concern to include environmental aspects into the public debate have lead the Environment Agency, the Jackson Environment Institute and the Centre for Advanced Spatial Analysis to commission a short term pilot study to evaluate the contribution of a GIS for decision support and for "discussion support".
\end{abstract}

In this paper, we describe how the state-of-the-art in geographic information (GI) and GI Science (GISc) can be used in a short term and limited project to achieve a practical and usable system. We are drawing on developments in information availability, as made accessible through the World Wide Web and research themes in GISc ranging from Multimedia GIS to Public Participation GIS.

\section{Introduction}

To meet the growing demand for housing it is forecast that an increase in 4.4 million homes will be required in the UK by 2016 (Urban Task Force, 1999). It has been proposed that brownfield ${ }^{1}$ redevelopment would provide the space needed for the extra housing.

Brownfield sites are an important component of the government's strategy to develop sustainable urban communities. Sustainable development incorporates economic, social and environmental needs. It is concerned with reconciling economic demands and social needs with the capacity of the environment to cope with pollution and to support human and other life (Environment Agency, 1998). However, there is a lack of integrated and comprehensive knowledge on the condition, location and management of brownfield sites

\footnotetext{
${ }^{1}$ For the purpose of this research the term 'brownfield site' was defined as an area which had previously been developed, but had since fallen derelict and may, or may not have existing buildings on it. No assumptions were made regarding contamination or pollution of each site.
} 
throughout the UK and little attention has been given to the contribution that brownfield sites make to biodiversity, nature conservation and amenity. The project described in this paper, funded by both the Environment Agency and University College London, aimed to evaluate the contribution of GIS to help remedy these issues.

It is in this context, that the National Land-Use Database (NLUD) should be mentioned. NLUD is aimed to provide a detailed geographical record of land use in England. Under current development and policy pressures, the partnership focuses on the collection and registration of brownfield related information (NLUD, 2000). However, although it is geographic, this system does not hold any information in a GIS format at the current stage. It is important to note that plans for such data collection exist. Furthermore, it is very difficult to integrate the NLUD point data with geo-referenced data sets such as Ordnance Survey (OS) Landline data. Without ignoring the value and importance of NLUD, we decided to focus on GIS oriented data collection and assembly.

In our project, we focused on urban brownfield sites in the Wandle Valley, South London as these have the most redevelopment potential and the greatest economic, environmental and social benefits. It was envisaged that such a system would provide a tool that can be used by property developers, planning professionals, local authorities, environmental bodies and organisation and last but not least - the local population.

Though we identified a wide range of stakeholders that are relevant to brownfield site redevelopment, we have not approached the system development with the idea that a single closed system could satisfy all. From the outset, it was clear that we would have to confront the opposing and what might seem as incommensurable views of different stakeholders. Nevertheless, it was felt that common information needs could be identified and accommodated. Furthermore, as the Environment Agency was a major stakeholder our main focus was on the environmental aspects of brownfield development.

It was decided that the system would be developed rapidly using PC based GIS. As the project was developed under severe time and resource limitations, we decided to rely on existing digital data sets as much as possible and to combine recent lessons from multiple areas of Geographical Information Science (GISc) research. This paper follows the development of the Brownfield GIS, pointing to the areas that informed it and the way in which current development in information access and Geographical Information (GI) were used to develop the system.

The paper starts with the identification of user requirement. We have used multiple approaches to identify and accommodate the requirements and needs of multiple stakeholders. Based on those requirements, we have built the system - by that we mean mainly the data collection and database organisation. As will be explained latter, it was felt that the system should be left as "open-ended" as possible, therefore the interface of the hosting GIS software (ArcView) was left relatively unchanged. In the following section we discuss several analyses that have been carried out with the system and the few customisations to the systems' interface that were deemed necessary. Following this description, we describe the exposition of the system to the different stakeholders, starting with a local activists who participated in a workshop where they learned about GIS capabilities and uses and then continuing with the more institutional users, such as Environment Agency officials, local authorities GIS and planning officers and the Government Office for London. We then turn to discuss the main lesson learned from this project that are relevant to the broader GISc community. This includes the rapid development of GIS and its database, the contribution of GIS to the brownfield debate and the use of GIS as "discussion support" tool. We conclude with some recommendations for future research. 
By its nature, the project is based on multiple research streams in GISc. We therefore felt that it is more appropriate to describe each of the area in the appropriate section of this paper and to combine them in the conclusion of this paper.

\section{User Requirements}

The integration of a user requirement study is now commonplace in general information systems design (Preece, 1995) and in GIS design (Reeve and Petch, 1999). They stem from studies in Usability Engineering and approaches like User Centred Design (Landauer, 1995) developed during the late 1980s. This aspect of GIS design received attention in the mid 1990s (Medyckyj-Scott and Hearnshaw, 1993; Nyerges et al., 1995). However, in their more familiar form, user requirements are connected to "task analysis" - a process of identifying the tasks that the user performs with the system (see for example Rasmussen, 1995). This approach requires quite a high-level of knowledge about users' work practices, activities and the ways in which the proposed information system can support these processes.

In the context of the brownfield GIS and especially in light of the emphasis on environmental information, such clear tasks and processes are hard to define and any focus on specific process (such as site selection for property developers) will limit the usefulness of the system to other stakeholders. Therefore, we have selected a more integrative and deliberative approach, which combines methods like interviews with key stakeholders, a seminar series with academics and practitioners and the use of an inclusionary workshop. These methods stem from the latest ideas about the meaning of participatory planning (Healey, 1997; Healey, 1998). Furthermore, current functionality of desktop GIS contains the needed elements to accomplish a wide range of tasks. As such, they represent a "toolbox" that can be adapted to the specific task (Batty, 1993). Therefore, it was necessary to use the desktop GIS with its set of extensions as a test bed for ideas and to envisage the development of more closed and specific system latter on, when the main requirements and need will be clarified.

The user requirement study started with the identification of potential users, as was described earlier. Even though a wide range of stakeholders was identified, the core elements of the system were set and defined by the professional group. The rational behind this decision is that those are the most likely users of such system. Even this user group was heterogeneous. It includes national government, local governance officials and London Boroughs. We have also considered Non-Governmental Organisations (NGO's), which are active in issues related to brownfield development.

Initially, the goals were defined through interviews with local and central government officials, representatives of the Environment Agency and others. These one-to-one interviews were augmented by views and ideas about brownfield development that came from a seminar series in UCL, held during 1999. These deliberative discussions focused around four themes (Bloomfield, forthcoming): First, the issues of definition, criteria and survey were raised. During this seminar, the question of "What is a brownfield site?" was examined. It became clear that though some general concepts exist, there is no exact definition that will suit all parties. The following seminar focused on data, users and site assembly processes. This seminar examined the information required by the various stakeholders. It clarified the difficulties that face developers, planners and others when they try to deal with brownfield sites. Such an operation includes the evaluation of the stock of sites or prioritises their development. The third seminar, titled public involvement, skills and knowledge considered the role of public participation and how 
should local and national interest groups should get involved in Brownfield site development. In the final seminar on future government structure, the focus turned to issues of governance and how bodies such as the GLA should act toward brownfield development These seminars participants came from a wide variety of backgrounds including policy makers, officials, representative of the commercial sector and academics.

Though these seminars were not dedicated to the development of the brownfield GIS per se, we have used the opportunity to bring issues of information access and availability to the discussion table, as to improve out understanding of what was needed. It is important to note that during all seminars, the issue of information needs and GIS integration were raised repeatedly by participants and there was no need to "divert" the discussion to raise these issues. Many participants felt that the integration of GIS with public access medium (the Internet) would be very useful. Data availability was an important issue and it was suggested that improved availability/accessibility to information on the system might benefit the public. Participants also voiced concern about the creation of a system designed with the objective of only aiding developers in their search for sites to suit their own purpose. Many participants also wanted to see contextual as well as site-specific information. By including environmental or policybased text on the system users would be able to view brownfield development as one component in the regeneration programme of a whole area. Regular updating of the system was also raised.

The seminar series and the interviews formed the first phase of the user requirement study. After this phase, the data sources for the system were gathered and the initial database created. These were followed by an evaluation of public requirement and need from such a system, as a workshop titled "Tools for planners, tools for the people?" revealed. This workshop is discussed later in the paper. First, to build a full picture of the database as it was used in the workshop, the process of data integration and analysis will be explained.

\section{Data Collection}

Traditionally, data collection and collation is considered as one of the complex and expensive task that relates to the creation of a GIS (Huxhold and Levinsohn, 1995). However, this situation is rapidly changing - at least for certain types of applications and activities $^{2}$. The availability of digital data set and the ability of commercial-off-the-shelf (COTS) software to integrate them easily was predicted in the early 1990's by Batty (1993) and it can be argued that we have entered this era of easier and faster collation of GI data-sets.

However, some caveats do exist and will continue to do so. Though the problem of precision that stem from constraints in hardware or software - a problem that blighted

\footnotetext{
${ }^{2}$ And for certain organisational settings. It is important to remember that the brownfield GIS was developed inside a university and research group that already collated massive amount of GI, a fact that reduces the costs of GI quite dramatically.
} 


\begin{tabular}{|c|c|c|}
\hline Name & Source & Description \\
\hline \multicolumn{3}{|c|}{ Green/Natural environment Data } \\
\hline $\begin{array}{l}\text { Sites of Special } \\
\text { Scientific Interest } \\
\text { (SSSI's) }\end{array}$ & $\begin{array}{l}\text { Environment } \\
\text { Agency }\end{array}$ & $\begin{array}{l}\text { Areas that have been designated by English Nature as } \\
\text { being of outstanding value for their flora, fauna or } \\
\text { geology under the Wildlife and Countryside Act } \\
\text { 1981. }\end{array}$ \\
\hline $\begin{array}{l}\text { Metropolitan Open } \\
\text { Land }\end{array}$ & $\begin{array}{l}\text { Environment } \\
\text { Agency }\end{array}$ & $\begin{array}{l}\text { Areas within the built-up area that are a significant } \\
\text { environmental resource to London. }\end{array}$ \\
\hline Rivers & $\begin{array}{l}\text { Environment } \\
\text { Agency }\end{array}$ & $\begin{array}{l}\text { This includes the Thames, Wandle and Beverley } \\
\text { Brook rivers. }\end{array}$ \\
\hline River Floodplains & $\begin{array}{l}\text { Environment } \\
\text { Agency }\end{array}$ & $\begin{array}{l}\text { The limits of the floodplain are defined by the peak } \\
\text { water level caused by rainfall of a } 1 \text { in } 100 \text { year } \\
\text { return period so such a storm has a } 1 \% \text { chance of } \\
\text { occurring in any particular year. The Environment } \\
\text { Agency has a statutory responsibility for all flood } \\
\text { defence matters concerning main rivers under the } \\
\text { Water Resources Act (1991). }\end{array}$ \\
\hline $\begin{array}{l}\text { Sites of } \\
\text { Metropolitan } \\
\text { Importance }\end{array}$ & $\begin{array}{l}\text { London } \\
\text { Ecology Unit }\end{array}$ & $\begin{array}{l}\text { These sites have the highest priority for protection } \\
\text { and contain the best examples of London's habitats } \\
\text { alongside rare species or assemblages of species or } \\
\text { sites that have particular significance within large } \\
\text { areas of heavily built-up London. }\end{array}$ \\
\hline $\begin{array}{l}\text { Sites of Local } \\
\text { Importance }\end{array}$ & $\begin{array}{l}\text { London } \\
\text { Ecology Unit }\end{array}$ & $\begin{array}{l}\text { These are sites of particular value to nearby residents } \\
\text { or schools and are particularly important in areas } \\
\text { otherwise deficient in nearby wildlife sites. }\end{array}$ \\
\hline $\begin{array}{l}\text { Sites of Borough } \\
\text { Importance (I \& II) }\end{array}$ & $\begin{array}{l}\text { London } \\
\text { Ecology Unit }\end{array}$ & $\begin{array}{l}\text { These sites are important in a borough-wide view but } \\
\text { have been split into two sub-categories on the basis of } \\
\text { their quality. Damage to any of these sites would } \\
\text { result in a significant loss to the borough. }\end{array}$ \\
\hline River Thames & $\begin{array}{l}\text { Ordnance } \\
\text { survey }\end{array}$ & $\begin{array}{l}\text { This file was produced from the Ordnance Survey } \\
\text { Meridian data. }\end{array}$ \\
\hline $\begin{array}{l}\text { Archaeological } \\
\text { Priority Zones }\end{array}$ & $\begin{array}{l}\text { Environment } \\
\text { Agency }\end{array}$ & $\begin{array}{l}\text { These are areas known to be of archaeological } \\
\text { importance because of past finds, excavations or } \\
\text { historical evidence. }\end{array}$ \\
\hline
\end{tabular}

Table 1. Data used in the Brownfield Project

\begin{tabular}{|c|c|c|}
\hline Name & Source & Description \\
\hline \multicolumn{3}{|c|}{ Infrastructure Data } \\
\hline Meridian Data & $\begin{array}{l}\text { Ordnance } \\
\text { Survey }\end{array}$ & $\begin{array}{l}\text { The Meridian dataset was used to show motorways, } \\
\text { A roads, B roads and minor roads and mainline } \\
\text { railway lines. }\end{array}$ \\
\hline Landline Data & $\begin{array}{l}\text { Ordnance } \\
\text { Survey }\end{array}$ & $\begin{array}{l}\text { This dataset was experimented with as a source of } \\
\text { detailed local information. }\end{array}$ \\
\hline $\begin{array}{l}\text { Overland and } \\
\text { Underground } \\
\text { Stations }\end{array}$ & Own & $\begin{array}{l}\text { Identifying a six-figure grid reference for each station } \\
\text { from a 1:20,000 street atlas collected this data. }\end{array}$ \\
\hline \multicolumn{3}{|c|}{ Socio/Economic Data } \\
\hline $\begin{array}{l}\text { Population per } \\
\text { Enumeration } \\
\text { District }\end{array}$ & $\begin{array}{l}\text { Manchester } \\
\text { Information \& } \\
\text { Associated } \\
\text { Services } \\
\text { (MIMAS) }\end{array}$ & Socio-economic data was provided through MIMAS \\
\hline
\end{tabular}




\begin{tabular}{|c|c|c|}
\hline $\begin{array}{l}\text { Main Shopping } \\
\text { Areas }\end{array}$ & $\begin{array}{l}\text { Unitary } \\
\text { Development } \\
\text { Plans (UDP's) }\end{array}$ & $\begin{array}{l}\text { These are centres providing a range of facilities for } \\
\text { the local population including shops, employment, } \\
\text { social and community facilities, transport services, } \\
\text { leisure and entertainment. }\end{array}$ \\
\hline \multicolumn{3}{|r|}{ Brownfield Site Data } \\
\hline Brownfield sites. & UDP's & $\begin{array}{l}\text { These are areas designated by each of the four } \\
\text { boroughs for redevelopment and range from vacant } \\
\text { land to empty shop units. }\end{array}$ \\
\hline $\begin{array}{l}\text { Wandle Valley } \\
\text { Regeneration } \\
\text { Partnership } \\
\text { (WVRP) } \\
\text { Brownfield Sites. }\end{array}$ & WVRP & $\begin{array}{l}\text { WVRP provided comprehensive information on nine } \\
\text { key development sites in the Wandle Valley Strategic } \\
\text { Employment Corridor. This data was in an analogue } \\
\text { format and was digitised onto the system using } \\
\text { ARC/INFO GIS. The sites are: } \\
\text { - } \quad \text { Cane Hill Park, Croydon } \\
\text { - } \quad \text { Former CMA site in Morden Road } \\
\text { - } \quad \text { Springfield Hospital, Tooting } \\
\text { - } \quad \text { Plough Lane Football Ground, Wimbledon } \\
\text { - } \quad \text { Beddington/Purley Way Cluster } \\
\text { - } \quad \text { Former Beddington Tip Site, Beddington Lane } \\
\text { - } \quad \text { Site North of Goat Road } \\
\text { - } \quad \text { Beddington Farmlands } \\
\text { - } \quad \text { Anchor Business Centre, Beddington Lane }\end{array}$ \\
\hline $\begin{array}{l}\text { National Land Use } \\
\text { Database (NLUD) } \\
\text { Brownfield Sites. }\end{array}$ & LB Sutton & $\begin{array}{l}\text { This data was supplied so it could be compared to the } \\
\text { Brownfield polygons digitised from the UDP maps. }\end{array}$ \\
\hline
\end{tabular}

Table 1 (continued). Data used in the Brownfield Project

earlier systems (Tomlinson, 1970) - has virtually disappeared, other issues like accuracy in GI (Burrough, 1986), conflation (Laurini and Thompson, 1992) or error propagation (Heuvelink, 1998) have not. While being aware of those issues and the possibility that specific questions cannot be answered without a complete, current and accurate brownfield database, for pragmatic reasons (such as the lack of information and the relative urgency in the requests from the user community), it was decided to trade-off high accuracy with information availability. Therefore, we have focused on the collation of data sets that can complement one another (especially in the environmental side). Another approach was to use known high-quality and up-to-date data sets, such as the Ordnance Survey (OS) data. Finally, we have tried to combine data sets that demonstrate the capabilities of GIS and spatial analysis in manipulation of socio-economic data (Martin, 1991) and environmental modelling (Goodchild et al., 1993). These data sets came from many diverse sources in both digital and analogue formats. Table 1 summarises the data set that we used to compile the system database.

The datasets categorised as green/natural environment data in Table 1 were chosen to show how environmentally and culturally sensitive areas could influence the brownfield redevelopment process. The data acquired from the London Ecology Unit (LEU) provides important information for developers - as the development of some of the brownfield sites might be inhibited by environmental concerns. This information was digitised especially for this project and was not available in digital form previously. Flood plains information was based on the Environmental Agency modelling and was integrated in order to demonstrate how the output of GIS based environmental modelling can be integrated and used in the project context. By simple overlaying, it was possible to 
identify brownfield sites with a potential risk of flooding - an issue of importance for developer and planner alike.

The infrastructure datasets in Table 1 were chosen as they provided a good backdrop over which to view other datasets. OS Meridian data was chosen so that the road network could be used for service area analysis as we describe latter. Aerial photography data taken from Cities Revealed ${ }^{\mathrm{TM}}$ was integrated into the system to cover some of the main brownfield sites. This was used to provide a rich, contextual information for the brownfield site and its surroundings. The system was programmed in such way that once the theme is viewed at a greater scale than 1:10,000 the aerial photography data replaces the more skeletal road network while the other information relating to the brownfield sites remains visible. By doing so, it is possible to put the sites in better context and to help users to orientate themselves. Figure 1 provides an example for this integration. In

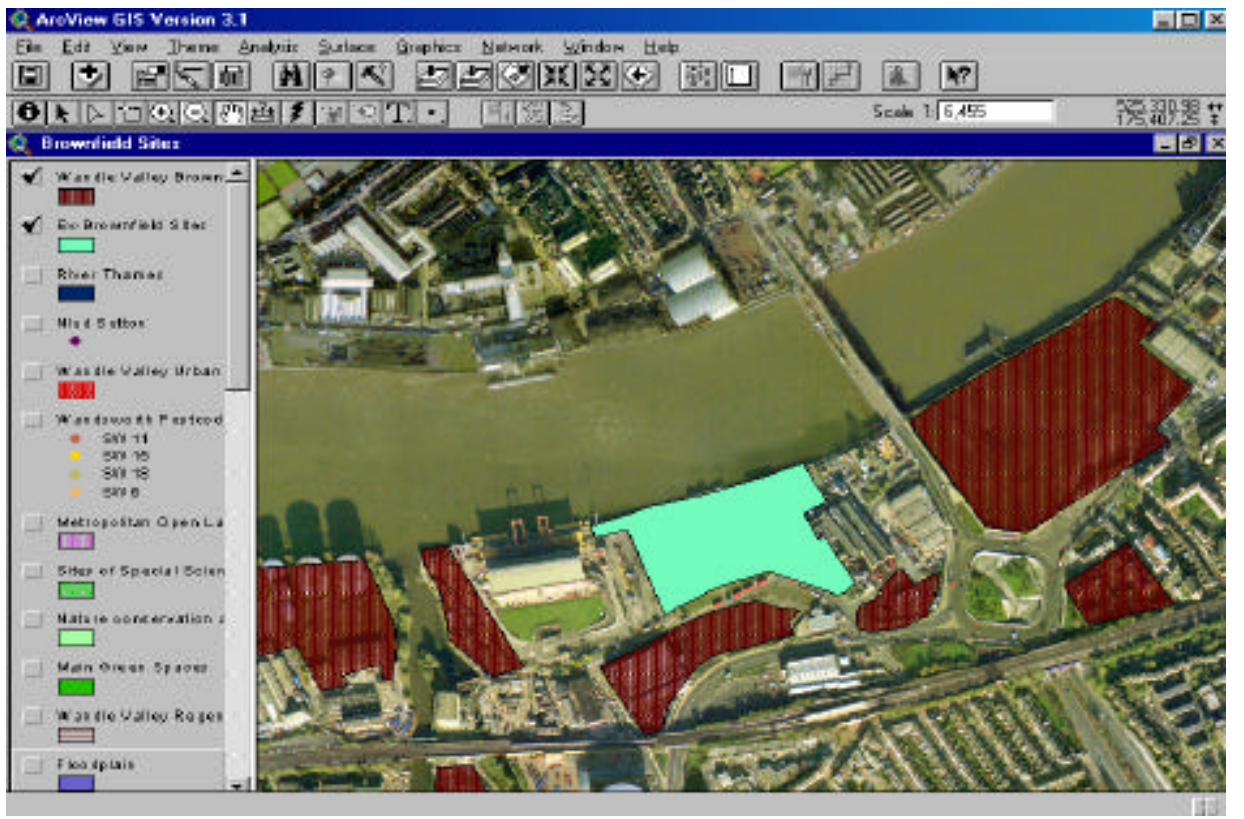

Figure 1. Aerial photography with overlaid digitised brownfield sites

the Figure, a concentration of sites (marked by transparent, yet distinctive polygons) near Wandsworth Bridge (south-west London) is presented with the aerial photograph.

The population socio-economic data was included to show which areas could already have high-density population despite being brownfield sites. They provide an opportunity to juxtaposition relatively abstract information (population density per enumeration district) with physical or modelled information. However, we have limited our use of the census data set, as it was felt that it becoming dated and too inaccurate. The shopping area data was included so network analysis could be carried out to establish which brownfield sites were within the each shopping centre service area.

The brownfield data shown in Table 1 that was derived from Unitary Development Plan (UDP) maps was used because it was the most recently available. Originally we planned to use data collected for the National Land-use Database (NLUD) until its lack of availability and its difficulty for integration with GIS was discovered. Instead older data 
was digitised from the UDP maps and a sample of NLUD point data for Sutton was used in comparison. The Wandle Valley Regeneration Partnership (WVRP) brownfield site data was used as a direct result of the iterative development process. The nine sites were deemed of high importance to the partnership.

Together, the data sets represent a cross section of the issues that influence brownfield site development, with an emphasis on the integration of environmental data sets with socio-economic and infrastructure data sets.

\section{Textual Data Collection And Multimedia}

The integration of multimedia with GIS started during the mid 1990s (Craglia and Raper, 1995). Soon after, GIS vendors started to integrate multimedia capabilities into their products. However, such integration was somewhat awkward and the multimedia functionality usually limited. The introduction of the World Wide Web as a medium that is inherently multimedia based followed soon after and changed the way in which multimedia was distributed and organised. It is important to note that the environmental application of multimedia GIS have used the precursor of the Web environment - the acclaimed HyperCard (Fonseca et al., 1995; Shiffer, 1995). However, the web browser, which is now part of any operating system makes the task of integrating multimedia into applications far easier. In some cases, the whole GIS application is integrated into the web browser, for example, Kingston et al. (2000) discussed such application that is more akin of traditional GIS, while others (Brown, 1999; Doyle et al., 1998) discussed the potential of integrating other multimedia forms with Web-based GIS. In the case of the brownfield GIS, we used the capabilities of the web browser and the WWW to integrate multimedia and information held in remote servers to augment the capabilities of the basic software package, without "struggling" with the limited multimedia capabilities of the specific software.

We have created web pages to provide information on brownfield sites, ex-brownfield sites, rivers and areas of nature conservation. These pages include textual information and pictures taken with a digital camera for various sites. Links were established from many polygons in the GIS to the Web browser so that further information, which is available on the Internet, could be easily and quickly accessed. Such links were established to the Environment Agency pages, which deal with regulations and the agency responsibility areas. Another major source for external information was the Wandsworth council web site, which provides public access to its planning register and enables access the applications that relate to specific brownfield. Some brownfield sites also had web pages set up by local independent groups and we have linked to these sites. One such site is the Battersea power station site, in which links were establish to the various stakeholders developers, local pressure group and the planning register.

\section{GIS Analysis And Customisation}

One of the most powerful features of any GIS is the capacity to carry out various spatial analyses quickly and easily. In the case of the brownfield GIS we chose to demonstrate these capabilities by implementing some overlay analysis - probably the most used analysis function of GIS since McHarg popularised it in the late 1960s (Mcharg, 1969). These analyses were integrated with outputs of network analysis and visualisation of 
service areas (Armstrong et al., 1992). Noteworthy is the integration of the EA floodplain analysis as a given layer of information.

The green data sets were used (see Table 1) to show which brownfield sites were over 400 metres from parkland (using buffer analysis). It was thought these sites would be less desirable for housing because of the reduced easy access to green areas. A more sophisticated network analysis was carried out. For example, service areas of $1 \mathrm{Km}$ from mainline and underground stations and weighted service areas for shopping centres (according to the size of the centre) were identified and the results were used those brownfield sites that apply to these criteria. It was thought that this process could be used to identify which brownfield sites met a certain number of planning criteria such as less than $1 \mathrm{Km}$ from a shopping centre, but within $1 \mathrm{Km}$ of a tube station.

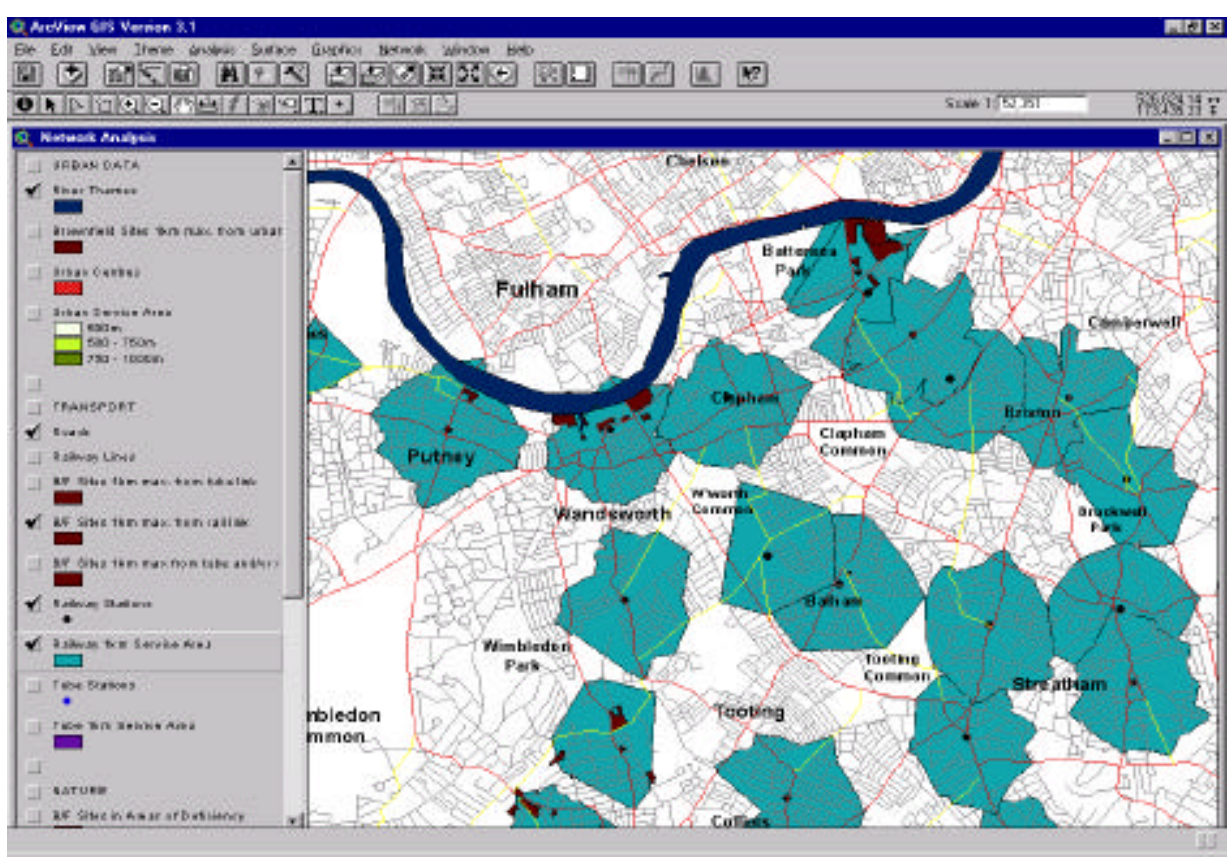

Figure 2: Network analysis showing the service areas around each overland railway station.

Figure 2 demonstrates the output of this analysis. The image focuses on Wandsworth area and the brownfield site polygons are represented in dark colour. The railway stations and their service area are the light blobs. Even though the analysis was carried in a dense urban area, not all the service areas are circular in shaped - which hints to the inappropriateness of simple buffer analysis in this case. For ease of use and for visualisation purposes, various overlay analyses were carried out. For example, brownfield sites that fall within the boundaries of the calculated flood risk area were selected and stored as a separate group. 
As was mentioned earlier, we tried to limit the customisation of the software. However, the few changes from the original, out-of-the-box functionality included the integration of a postcode based search tool. This was done to enable the use of an easy and familiar geographical reference, which is common and accessible to a wide range of users (Raper et al., 1992). The second change was the connection to web based information browsing we have mentioned before. Figure 3 provide an example for this integration and shows the GIS at the upper frame, while the web browser with the detailed information in the lower one. Finally, for the visualisation scheme, we chose to base the cartographic representation on familiar, well-labelled Ordnance Survey data.

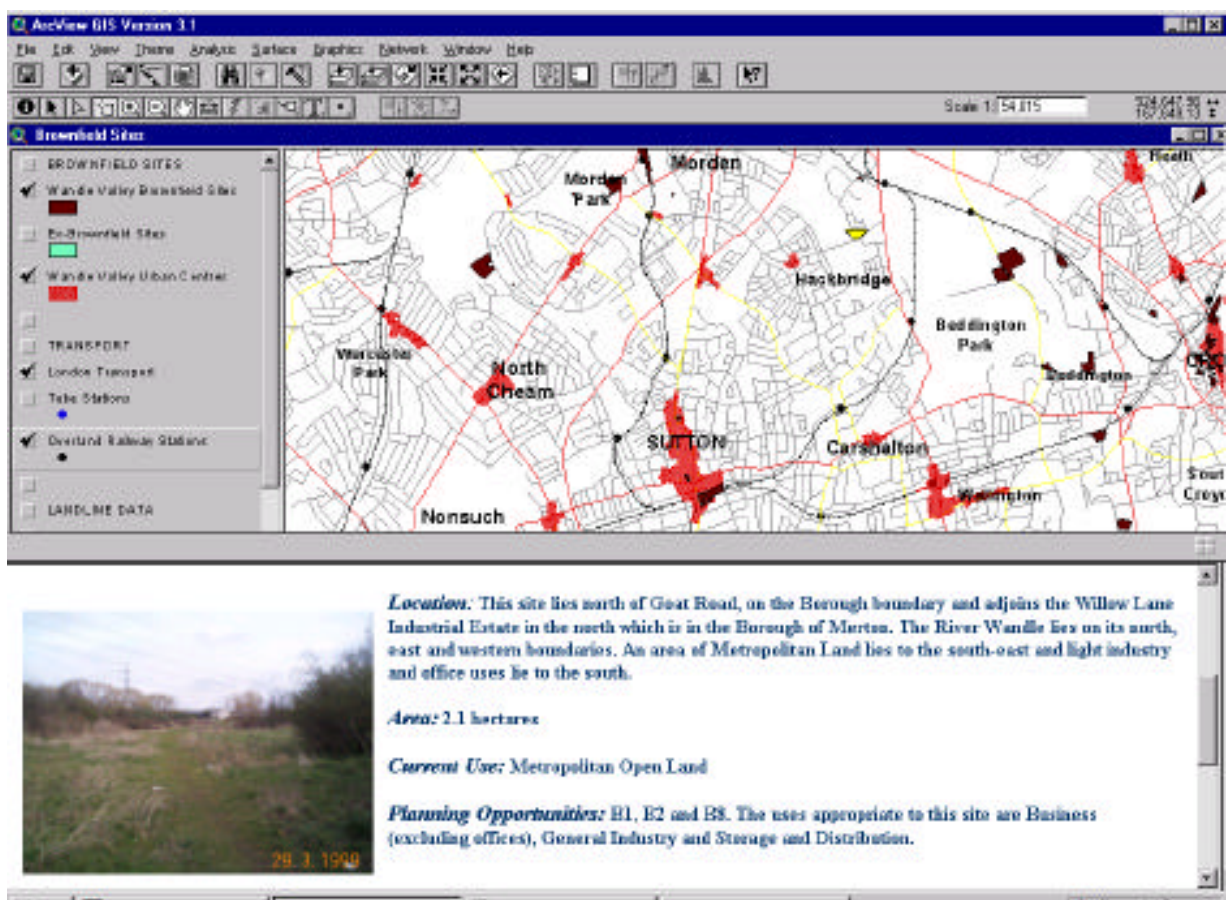

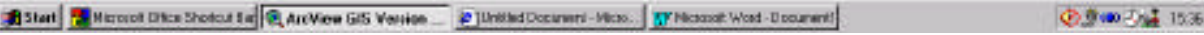

Figure 3. Hotlinks from each brownfield site to web-based information pages.

\section{The Public Participation Workshop}

During the first period of system development, an opportunity for testing its use for public participation purposes emerged. This was carried out with a separate grant, which helped in establishing a network of experts with knowledge in planning, geomatics, GIS, public participation and inclusionary processes and environmental research. This element enabled the integrate the views and needs of this audience to the project scheme.

Public Participation GIS (PPGIS) is a current active research theme in GISc. The origins of this research are usually traced to from collaborative uses of GIS (Densham et al., 1995) and GIS critique, epitomised by the publication of "Ground Truth" (Pickles, 1995). The main research themes emerge during NCGIA Initiative 19: GIS and Society (Harris and Weiner, 1996) where the concept itself was suggested and accepted (Schroeder, 
1997) ${ }^{3}$. PPGIS has emerged as a test-bed for techniques, methodologies, ideas and discussion about the social implication of GIS technology. In recent years, this area has grown extensively and the project team consulted the material that emerged from this field during the design of the workshop. Though some previous activities focused on web-based PPGIS (Carver and Openshaw, 1995; Craig, 1998; Kingston et al., 2000), the team involved in the Brownfield project preferred a more personal and contextual approach which is common in collaborative planning research. There is some evidence for integrating similar methodologies in PPGIS (Al-Kodmany, 1998), but it was felt that the experience that was gathered in running various participative techniques, like in-depth group discussions or focus groups, could contribute to this field (see Burgess et al., 1998a; Burgess et al., 1988; Harrison et al., 1998). Furthermore, the approaches that were used to design and run the workshop, were based on an inclusionary and participatory research agenda which relates to many areas in planning and governance (Burgess et al., 1998b).

Based on these groundings, the workshop aimed to achieve two major goals. First, to enhance our understanding of users' need and requirement and secondly to explore the adaptability of participatory and inclusionary approaches that are more common in cultural geography research to PPGIS. In this paper, we will focus more on the requirements and needs, as the second aspect deserves a special and separate attention. As for the practical aspect of the workshop, we aimed to enable participants to learn something about GIS and its uses, while learning from them what they expect to find in such system. Fifteen people encompassing a wide range of computer skills were recruited from community and other voluntary groups based in Wandsworth.

The workshop took place at UCL and was held as a half-day session divided into four parts. The workshop started with introduction to the aims of the day and the technology. This introduction was as free from jargon as possible and gave an overview of the richness of information in the system while demonstrating basic GIS technology such as layering of information. Following this introduction, the participants divided into small groups so that they would all have an opportunity to use the GIS "hands-on". A "GIS expert' (a person with experience with the software and the content of the system) and a facilitator (a person with expertise in group work) supported each group. Tape recorders were used to record the session and Lotus ScreenCam software was used to capture the operations of the computer system. This session lasted for over 90 minutes. Once this session ended and the participants gain familiarity with the system, its capabilities and content, we have braked for a well-earned lunch, in which all the facilitators and participants had an informal opportunity to raise issues and to share experiences.

The next part of the workshop was conducted in two groups, divided according to gender. Each group conducted a one-hour discussion on the views of the participants on the system and the systems use. The discussion tried to expand beyond the immediate experience of GIS use, as issues like public access to the system, accuracy and trust were raised. The reason for the gender divide was as a result of previous experience of the facilitators involved in previous group work. To conclude the day, a plenary session was held and provided more feedback through a debriefing questionnaire.

Participants felt that the system had some potential for use as a tool to provide them with a means of presenting their cases for local issues to planners and local authorities in a pro-active manner. They felt that the use of such a system might allow for a more

${ }^{3}$ For a review of the origins and background, the interested reader is referred to (Schroeder, 1997) and (Chrisman, 1999a). 
informed debate between the public and local authority representatives on a more even footing. However, the public participation day did help to highlight a number of issues. Specifically, it proved that even novice users of GIS grasp the ideas of overlaying quickly and expected to see such analysis results. Furthermore, they quickly realise GIS ability to pursue and demonstrate 'what if?' scenarios of change

In terms of physical access to the information on the system, many of the participants felt that there were large sections of the population that might be excluded if the information was just provided over the Internet. One suggestion for a possible solution was that the Council should provide access to the system in local libraries. Participants were also concerned about the availability of software and the cost implications to a local group or individuals. Furthermore, some felt that many people would not have the necessary computer literacy or expertise to use the system and that if they had been left on their own, they would not have got very far. This would pose a real problem even if the system were available in libraries, as some people felt they would lack the confidence to ask for help. It is important to note that most of these aspects have been identified in the PPGIS literature (Kingston et al., 2000) and that some have even provided an account for the use of GIS by local community group (Ghose, 1999).

As for the issue of information requirement, the workshop helped us in consolidating the data sets needs. The participants felt that the system would benefit from a range of additional data sets such as proposed parking schemes, traffic densities and flows, schools, cycle routes and landmarks such as local rivers. Furthermore, they felt that upto-date information on population density; schools and other socio-economic variables would be helpful. Such information might enable pro-actively from the local community themselves. However, the network analysis, which showed up areas that were not well served by public transport, was seen as valuable. Participants wanted to be able to add their own information to the GIS so as to ensure that the planning process was not driven entirely by the concerns of 'experts'. Many were enthusiastic about the new possibilities for gaining new knowledge about their local area offered by the GIS. Noteworthy, some participants were unhappy with the level of data accuracy and reliability - especially the lack of local information (like local amenities or the type of shopping that each shopping area provides). On the organisational settings, participants were not convinced that updating of the system would be done regularly if it were the responsibility of the local authorities. Instead academic institutions were seen as reliable agents who could take responsibility for updating the GIS.

The PPGIS workshop identified some discrepancies in the system in relation to the availability of more detailed information on the surroundings of each brownfield site - it was noted that most group felt "disoriented" once the zoomed in to a specific area and the skeletal Meridian data set became too abstract. As a result, Aerial photographs were added around major brownfield sites.

\section{Exposing The System To Potential Users}

After the workshop, the brownfield GIS was further developed and completed. Once the system was ready for presentation and discussion, a series of presentations were arranged. During these presentations, the system was presented to representatives of bodies and agencies with an interest in brownfield issues. Each presentation was followed by a 1- 
hour discussion on the merits and the discrepancies of the specific system and the use of GIS for this issue. The audience for the presentations included representatives from the Environmental Agency professional, both those involved in the day-by-day activities of the agency and the IT and GIS support personnel. Another presentation included representatives from local authorities and the Government Office for London.

A major issue that was raised by professionals who work daily with the planning system and with GIS was the issue of copyright and the cost of database creation and maintenance. These issues were seen as the major obstacles before the implementation of a full-scale brownfield GIS for London could be developed. The participants of the presentations agreed on the necessity to have such a database and that it would streamline brownfield development and improve the level of discussion. These presentations provided insights into the future uses and development of such a system by the most likely users.

\section{Discussion}

The lessons from the brownfield GIS development process can be divided into three areas. First, we will comment on the nature of the development cycle and reflect on the state-of-the-art in GIS, GI and GISc. Second, we will comment on the contribution of GIS to the current debate about brownfield development. We will close with some comment and questions about current PPGIS research and the ways in which our project fits to the wider research agenda.

\section{Iterative Development}

The system was developed using an iterative approach by using a series of seminars, demonstrations and a one-day public-participation workshop. This provided invaluable personal contact during the development process.

The use of commercial-off-the-shelf products helped in implementing the project in a very short time scale and with very limited resources (only one person was dedicated fulltime to the project). The support and help from various stakeholders helped immensely in constructing a useful database. This iterative approach might seem an impediment to the development of the system, but instead it actually helped in discovering any missing data sets. For example, during a presentation to the workshop team, the need for postcode data sets emerged which was later integrated into the system.

This cycle is very similar to the concepts and ideas that are now commonplace in Rapid Application Development (RAD) (Reeve and Petch, 1999). In the brownfield GIS we have adopted RAD principles (rapid cycle of assembly, tests, exposure to the user community and so on) and given them equal importance in GIS database construction and development.

As the literature that we have reviewed in earlier sections demonstrates, we relied on techniques and approaches that were part of cutting-edge research project only 5 years ago. Indeed, the development in desktop GIS, the capabilities of the software that we have used answers most of the wish list that was described only few years ago for "True desktop GIS" (Elshaw-Thrall and Thrall, 1999). Furthermore, the proliferation of of-theshelf, ready to use GI products (like Cities Revealed) makes the task of GIS database assembly much easier. True, our organisational settings meant that it was easier for us to 
obtain and use these GI data sets and others might find that the resources needed to purchase them are quite significant. This is an issue that often rises in the GI literature (Pipes and Maguire, 1997). However, as a proof of concept we have demonstrated that the infamous 80/20 equation between data acquisition cost and other cost of GIS project (Huxhold and Levinsohn, 1995), might be changing and soon may become irrelevant.

\section{The Role Of GIS In The Brownfield Debate}

The need to achieve a consensus among all relevant parties, including the public was stressed in Agenda 21, a global action programme for sustainable development (UN, 1992). The Rio Earth Summit (1992) recommended the active participation of citizens along with governments in the implementation of the Rio agreements. However, this is not easy as it implies the need to adopt new decision making methods that go beyond traditional consultancy frameworks to involve groups and individuals in a partnership approach. This approach emphasises the need to identify a range of issues and concerns and to resolve differences of opinion and conflicts between different interests, so that solutions are designed to meet various points of view (Environment Agency, 1998). The implementation of such an approach was tested as part of this project through the four Brownfield Seminars in February and the Public Participation workshop in June 1999.

The completed system provides a useful tool that demonstrates the advantages that GIS has over more traditional mapping methods; its ease of integrating diverse data sets, updating and Internet links to name a few. However, throughout its development many issues were raised especially relating to the points raised during the iterative development process.

By its very nature, a GIS is data-driven and its success is dependent on the availability of data. It is unfortunate that the NLUD is not more GI savvy and the integration of it with GIS will not be trouble free. However, when considering the urgency of the task to identify brownfield, it is believed that it can be integrated (even as point data) to a GIS scheme and therefore it will be possible to use it as part of analysis of the sort we described above. We have decided to obtain brownfield site information from the UDP's for each local authority, in spite of the lack of currency. In a way, we have demonstrated the potential of polygon-based NLUD.

We have selected an approach of rapid digitisation and integration of multiple data sets, knowing that the database accuracy and precision could be questionable. Some inaccuracy does occur in the digitising and geo-referencing process and as a result some of the data sets did not always correspond to each other perfectly. However, it is stressed that the system was not intended to be used by surveyors for pinpoint accuracy, but more as an information tool to try and encourage more public interest in the planning process and highlight the need for more sustainable development.

Finally, we should note that GIS holds the potential raised by those who have been exposed to the system (participants in the workshop, during the seminars and the presentation) that it should aim to predict the brownfield sites of tomorrow by considering sectors that are likely to produce new sites. Naturally, such information can be politically and commercially sensitive and their inclusion or exclusion is very subjective. However, such potential might be a challenging, yet interesting source for future research. 


\section{Public Participation GIS And Exploratory GIS}

The approach that we have presented during the development of the brownfield GIS and in the course of this paper can be termed "discussion support tool". By this, we mean the use of GIS not just as a decision support tool, where alternatives are explored, quantified and compared using analytical models (Densham, 1991) but more akin to the Nicholas Negroponte concept of "tools to think with for the world at large" (Bennahum, 1995). The focus in this mode of GIS use is not necessary on its geodetic or analytic capabilities (although they do play a major role), but rather on the visual and contextual exploration of the problem situation and issues connected to it. This mode of use relies heavily on GIS capabilities to work "at the speed of discussion" (as one of the participants described it) and the ability of the expert user to understand, facilitate and perform the analysis on the spot using the full toolbox of GIS capabilities.

It is exactly at that point that our approach differs from the one offered by Web-based PPGIS ones (Carver et al., 1998; Craig, 1998; Kingston et al., 2000). Following previous discussion about expected functionality of GIS packages (see Elshaw-Thrall and Thrall, 1999) we argue that for a 'true' PPGIS a 'true' GIS is needed. Classic definitions of what GIS constitute (for example Maguire, 1991), the GIS principles offered by the International Association of Assessing Officials - IAAO (Huxhold and Levinsohn, 1995) all discuss the analytical capabilities as part and parcel of what GIS is. Earlier definition went as far as declaring that a specific functionality (polygon overlay) is needed as "proof" for GIS (Chrisman, 1999b). In the same paper Chrisman is offered a more open and inclusive definition of GIS, but also commented about definitions that are too inclusive (Rhind's):

"In his attempt to be universal, Rhind offers a definition that is so loose that the address book function of a hand-held pocket planner is indistinguishable from a fullfunction GIS workstation. ..." (Chrisman, 1999b, p. 181).

Similar emphasis on processing and interpretation of spatial data can be found in recent GIS textbooks (for example Heywood et al., 1998). Therefore, some questions must be raised about the needed functionality of Web-based PPGIS. Current examples clearly lack these analytic capabilities (or carry it in a closed form as in Carver and Openshaw, 1995). Maybe the time has come to learn from the lessons of the development of general GIS and to open up the question of which functions are needed to make a 'true' PPGIS. This is not merely a question of definition. The importance of GIS is not in its capability to display interactive maps but in the ability to analyse spatial data. A better understanding of the analytical operations needed and the development of more accessible interfaces to perform these will provide some directions for future research.

Another important lesson about PPGIS is the opportunity that it opens for collaborative research among various expertise in Geography and related fields. One of the major reasons for the success of our workshop - at least as expressed by participants, was the integration of experience GISc researchers and researchers with a long track in participatory and inclusionary processes. We hope to report on this collaboration in more details soon ${ }^{4}$.

From our experience we tend to agree with Harris and Wiener (Harris and Weiner, 1996) assertions as the fundamentals of successful PPGIS implementations:

\footnotetext{
${ }^{4}$ For a preliminary report on the UCL Brownfield Research Network, see Aurigy et al.
} 1999. 
- Agency driven, but not top-down nor privileged toward conventional expert knowledge

- Local knowledge is valuable and expert

- Broaden access base to spatial information technology and data

- Incorporate socially differentiated multiple realities of landscape

- Integrate GIS and multimedia

- Explore the potential for more democratic spatial decision making through greater community participation

- Assume that spatial decision making is conflict ridden and embedded in local politics

A valuable finding of our workshop is that many of those who are the potential users of PPGIS (like our workshop participants) identified some of these principles and expresses them without prior knowledge of the research literature.

\section{Conclusions}

Despite the issues related to accuracy and precision and the lack of current data, there are many advantages of the brownfield GIS over more traditional forms of data capture. By using the approach we described, we have managed to integrate different data sets so comparisons can quickly be made between brownfield sites and environmental data sets. Additional information such as ownership, size of the site and environmental and transport data can quickly and easily accessed each brownfield site in a web environment. It is assumed that the rollout of NLUD during 2000 will open-up possibilities to integrate direct access to its database, using a Web based interface similar to the one described above. The use of GIS can also enable the creation of a hierarchy of development suitability by comparing brownfield proximity to public amenities such as town centres and public transport.

Despite the drawbacks to the system, the finished product was well received by both. It is hoped that this project demonstrated what GIS can achieve for the brownfield debate and furthermore how important it is for the development process to be iterative. Planners need to investigate the spatial relationships between natural, physical and socio-economic variables to explore and evaluate different alternative planning scenarios. Therefore, the value of GIS for urban and environmental planners is its ability to integrate diverse data sets under a common spatial theme.

\section{Acknowledgement}

Figures reproduced from the Ordnance Survey mapping with the permission of the controller of Her Majesty's Stationery Office (c) Crown Copyright. Unauthorised reproduction infringes Crown Copyright and may lead to prosecution or civil proceedings. University College London ED 2813362000 


\section{References}

Al-Kodmany, K. (1998) GIS and the Artist: Shaping the Image of a Neighborhood in Participatory Environmental Design In Empowerment, Marginalization, and Public Participation GIS, Santa Barbara, CA,14-17th Oct.,1998 Available World Wide Web URL http://www.ncgia.ucsb.edu/varenius/ppgis/papers/al-kodmany.html (Accessed $3^{\text {rd }}$ May 1999).

Armstrong, M. P., Densham, P. J., Lolonis, P. and Rushton, G. (1992) Cartographic Displays to Support Locational Decision Making, Cartography and Geographic Information Systems, 19(3), pp. 154-164.

Aurigi, A., Batty, S., Bloomfield, D., Boott, R., Clark, J., Haklay, M., Harrison, C., Heppell, K., Moreley, J. and Thornton, C., 1999, UCL Brownfield Research Network, University College London, London.

Batty, M. (1993) Using Geographic Information Systems in Urban Policy and PolicyMaking, In Geographic Information Systems, Spatial Modelling and Policy Evaluation,(Eds. Fischer, M. M. and Nijkamp, P.), Springer-Verlag,Berlin, pp. 51-72.

Bennahum, D. S. (1995), Meme 1.07, Available E-mail newslaetter, URL: http://www.memex.org/meme1-07.html (Accessed 26 ${ }^{\text {th }}$ Aug 1999)

Bloomfield, D. (forthcoming) Towards an Evaluative Framework for Public Policy Discourses: London's Brownfields and a New Governance Relation, PhD thesis, University of London, London.

Breheny, M and Hall, P (1996) The people - Where will they go? TCPA, London

Brown, I. M. (1999) Developing a Virtual Reality User Interface (VRUI) for Geographic Information Retrieval on the Internet, Transactions in GIS, 3(3), pp. 207-220.

Burgess, J., Clark, J. and Harrison, C. M. (1998a) Respondents' Evaluations of a CV Survey: A Case Study Based on an Economic Valuation of the Wildlife Enhancement Scheme, Pevensey Levels in East Sussex, Area, 30(1), pp. 19-27.

Burgess, J., Harrison, C. M. and Filius, P. (1998b) Environmental Communication and the Cultural Politics of Environmental Citizenship, Environment and Planning A, 30(8), pp. 1445-1460.

Burgess, J., Harrison, C. M. and Limb, M. (1988) People, Parks and the Urban Green: A Study of Popular Meanings and Values for Open Spaces in the City, Urban Studies, 25(6), pp. 455-473.

Burrough, P. A. (1986) Principles of Geographical Information Systems for Land Resources Assessment, Clarendon Press, Oxford.

Carver, S., Kingston, R. and Turton, I. (1998), Accessing GIS over the Web: An Aid to Public Participation in Environmental Decision Making, Available World Wide Web, URL: http://www.ccg.leeds.ac.uk/vdmisp/publications/paper1.html (Accessed 11th Dec 1998)

Carver, S. and Openshaw, S. (1995) Using GIS to Explore the Technical and Social Aspects of Site Selection In Conference on the Geological Disposal of Radioactive Wastes, Royal Lancaster Hotel, London, March 1995.

Chrisman, N. (1999a) Full Circle: More Than Just Social Implications of GIS In GISOC99Ed,^(Eds, ence) Full Circle: More Than Just Social Implications of GIS University of Minnesota,20-22 June,1999a Available URL: http://www.geog.umn.edu/gisoc99/chrisman.htm (Accessed $5^{\text {th }}$ Jul 1999).

Chrisman, N. R. (1999b) What Does 'GIS' Mean?, Transactions in GIS, 3(2), pp. 175186. 
Craglia, M. and Raper, J. (1995) GIS and Multimedia, Environment and Planning B, 22(6), pp. 634-636.

Craig, W. J. (1998) The Internet Aids Community Participation in the Planning Process In Groupware for Urban Planning Lion, France, $5^{\text {th }}$ Feb 1998.

Densham, P. J. (1991) Spatial Decision Support Systems, In Geographical Information Systems: Principles and Applications,(Eds. Maguire, D. J., Goodchild, M. F. and Rhind, D.), Longman Scientific and Technical, Harlow, England, pp. 403-412.

Densham, P. J., Armstrong, M. P. and Kemp, K. K. (1995), Collaborative Spatial Decision-Making: Scientific Report for the Specialist Meeting, National Center for Geographic Information and Analysis, Santa Barbara, CA.

Doyle, S., Dodge, M. and Smith, A. (1998) The Potential of Web-Based Mapping and Virtual Reality Technologies for Modeling Urban Environments, Computers, Environment and Urban Systems, 22(2), pp. 137-155.

Elshaw-Thrall, S. and Thrall, G. I. (1999) Desktop GIS Software, In Geographical Information Systems, (Eds. Longley, P., Goodchild Michael, F., Maguire, D. J. and Rhind, D.), John Wiley \& Sons Inc.,New York, pp. 331-345.

Environment Agency, (1998) SD12 Consensus Building for Sustainable Development, Sustainable Development publication series.

Fonseca, A., Gouveia, C., Camara, A. and Silva, J. P. (1995) Environmental Impact Assessment with Multimedia Spatial Information Systems, Environment and Planning B, 22(6), pp. 637-648.

Ghose, R. (1999) Use of Information Technology for Community Empowerment: Transforming Geographical Information Systems into Community Information Systems In GISOC99 University of Minnesota, 20-22 June,1999 Available World Wide Web URL: http://www.geog.umn.edu/gisoc99/ (Accessed $5^{\text {th }}$ Jul 1999).

Goodchild, M. F., Parks, B. O. and Steyaert, L. T. (Eds.) (1993) Environmental Modeling with GIS, Oxford University Press, New York.

Harris, T. M. and Weiner, D. (1996), GIS and Society: The Social Implications of How People, Space and Environment Are Represented in GIS, National Center for Geographic Information and Analysis, Santa Barbara,CA.

Harrison, C. M., Burgess, J. and Clark, J. (1998) Discounted Knowledges: Farmers' and Residents' Understandings of Nature Conservation Goals and Policies, Journal o Environmental Management, 54(4), pp. 305-320.

Healey, P. (1997) Collaborative Planning : Shaping Places in Fragmented Societies, UBC Press, Vancouver.

Healey, P. (1998) Collaborative Planning in a Stakeholder Society, Town Planning Review, 69(1), pp. 1-21.

Heuvelink, G. B. M. (1998) Error Propagation in Environmental Modelling with GIS, Taylor \& Francis, London.

Heywood, I., Cornelius, S. and Carver, S. (1998) An Introduction to Geographical Information Systems, Longman, Harlow.

Huxhold, W. E. and Levinsohn, A. G. (1995) Managing Geographic Information System Projects, Oxford University Press, New York.

Kingston, R., Carver, S., Evans, A. and Turton, I. (2000) Web-Based Public Participation Geographical Information Systems: An Aid to Local Environmental DecisionMaking, Computers,Environment and Urban Systems, 24(2), pp. 109-125.

Landauer, T. K. (1995) The Trouble with Computers: Usefulness, Usability, and Productivity, MIT Press, Cambridge, Mass. 
Laurini, R. and Thompson, D. (1992) Fundamentals of Spatial Information Systems, Academic Press, London.

Maguire, D. J. (1991) An Overview of Definition of GIS, In Geographical Information Systems: Principles and Applications, (Eds. Maguire, D. J., Goodchild, M. F. and Rhind, D.), Longman Scientific and Technical,Harlow, England, pp. 9-20.

Martin, D. (1991) Geographic Information Systems and Their Socioeconomic Applications, Routledge, London, Routledge. 1991.

McHarg, I. L. (1969) Design with Nature, Published for the American Museum of Natural History [by] the Natural History Press, Garden City, N.Y.

Medyckyj-Scott, D. and Hearnshaw, H. M. (1993) Human Factors in Geographical Information Systems, Belhaven, London.

NLUD - National Land Use Database, 2000, Previously Developed Land (PDL) - Data Specification, Available World Wide Web http://www.nlud.org.uk (Accessed $1^{\text {st }} \mathrm{Jul}$ 2000).

Nyerges, T. L., Mark, D. M., Laurini, R. and Egenhofer, M. J. (Eds.) (1995) Cognitive Aspects of Human-Computer Interaction for Geographic Information Systems, Kluwer Academic Publishers, Dordrecht, The Netherlands.

Pickles, J. (1995) Ground Truth: the Social Implications of Geographic Information Systems, Guilford Press, New York.

Pipes, S. and Maguire, F. (1997) Behind the Green Door In Mapping Awareness, 11(10), pp. 28-29.

Preece, J. (1995) Human-Computer Interaction, Addison-Wesley Pub. Co, Wokingham, England.

Raper, J. F., Rhind David, W. and Shepherd, J. (1992) Postcodes : The New Geography, Longman Scientific \& Technical, Harlow, Essex.

Rasmussen, J. (1995) Geographic Information Systems, Work Analysis, and System Design, In Cognitive Aspects of Human-Computer Interaction for Geographic Information Systems,(Eds. Nyerges, T. L., Mark, D. M., Laurini, R. and Egenhofer, M. J.), Kluwer Academic Publishers,Dordrecht, The Netherlands, pp. 373-391.

Reeve, D. E. and Petch, J. R. (1999) GIS, Organisations and People: A Socio-Technical Approach, Taylor \& Francis, London.

Schroeder, P. (1997) GIS in Public Participation Settings In UCGIS 1997 Annual Assembly and Summer Retreat Bar Harbor, Maine,15th-21st June,1997 Available World Wide Web

URLhttp://www.spatial.maine.edu/ucgis/testproc/schroeder/UCGISDFT.HTM

(Accessed 16 ${ }^{\text {th }}$ Aug 1999).

Shiffer, M. J. (1995) Environmental Review with Hypermedia Systems, Environment and Planning B, 22(3), pp. 359-372.

Tomlinson, R. F. (Ed.) (1970) Environment Information Systems, International Geographical Union, Ottawa, Canada.

UN (1992), Agenda 21, United Nations, Rio de Janeiro.

Urban Task Force (1999) Toward Urban Renaissance, DETR, London 